\title{
Bioteknologi Fermentasi Jerami Padi Tinggi Nutrisi, Guna Meningkatkan Kemandirian dan Kesejahteraan Peternak di Desa Kalibendo
}

\author{
Roni Yulianto $^{1}$, Nurwidodo ${ }^{2}$, Desy Cahya Widianingrum ${ }^{3}$, Himmatul Khasanah ${ }^{4}$ \\ Universitas Jember, Jl. Diponegoro, Poncogati, Curah Dami, Kabupaten Bondowoso, Jawa Timur \\ 68251 \\ Email: roniyulianto99@gmail.com ${ }^{1}$
}

\begin{abstract}
ABSTRAK
Kabupaten Lumajang memiliki lahan pertanian dan perkebunan dengan komoditi utamanya adalah tanaman padi, jagung dan kopi. Banyak sekali limbah yang belum termanfaatkan, berawal dari program KKN, potensi daerah di Desa Kalibendo, Kecamatan Pasirian, Kabupaten Lumajang sangat potensial untuk dikembangkan salah satunya Bioteknologi fermentasi jerami padi tinggi nutrisi, guna meningkatkan kemandirian dan kesejahteraan peternak di Desa Kalibendo, Kecamatan Pasiria, Kabupaten Lumajang. Pendampingan dari instansi terkait edukasi dalam bioteknologi pengolahan pakan berkualitas secara mandiri dari bahan baku lokal yang ada dari limbah pertanian setempat dapat memenuhi ketersediaan pakan ternak baik dari segi kualitas maupun kuantitas. Pemanfaatan Limbah jerami padi menggunakan bioteknologi fermentasi untuk pakan ternak ruminansia (sapi, kambing/domba) perlu terus dikembangkan, karena dengan fermentasi dapat meningkatkan kualitas nutrisi pakan ternak, dan memanfatkan limbah hasil pertanian menjadi berdaya guna sehingga tidak terbuang begitu saja, dan bisa digunakan dalam jangka waktu yang lama untuk ketersediaan pakan ternak pada saat musim kemarau atau disaat hijauan sudah mulai berkurang. Target dari Program Pengabdian Desa Binaan yaitu bersama dengan pemerintah Desa Kalibendo melakukan pemberdayaan petani-peternak dalam pengolahan pakan ternak fermentasi, sehingga dapat mewujudkan kemandirian dan kesejahteraan peternak.
\end{abstract}

Kata Kunci: Pakan Ternak; Bioteknologi; Jerami Fermentasi; Ternak Ruminansia

\begin{abstract}
Lumajang Regency has extensive agricultural and plantation land, especially rice, corn, and coffee crops, a lot of waste that has not been utilized. Starting from the KKN program, regional potential in Kalibendo Village, Pasirian District, Lumajang Regency is very potential to be developed, one of which is Biotechnology for fermented rice straw with high nutrition, to increase the independence and welfare of breeders in Kalibendo village, Pasiria district, Lumajang Regency. Assistance from educational institutions related to quality feed processing biotechnology independently from existing local raw materials from local agricultural waste can meet animal feed availability in terms of quality and quantity. Utilization of rice straw waste uses biotechnology for ruminant animal feed (cows, goats/sheep), it needs to be continuously developed because fermentation can improve the nutritional quality of animal feed, and utilize agricultural waste to be efficient so that it is not wasted, and can be used in a long period for the availability of fodder during the dry season when the forage has diminished. The Assisted Village Service Program's target is to collaborate with the Kalibendo Village government to empower farmers in the processing of fermented feed so that they can realize the independence and welfare of the breeders.
\end{abstract}

Keywords: Animal feed, Biotechnology, Fermented straw, Ruminants. 


\section{PENDAHULUAN}

Kabupaten Lumajang merupakan daerah sentra pengembangan komoditas pertanian dan peternakan. Sektor pertanian dan peternakan merupakan salah satu sumber pendapatan utama bagi petani peternak Desa Kalibendo, Kecamatan Pasiria, Kabupaten Lumajang dengan komoditas utama padi, jagung, dan palawija. Kabupaten lumajang memiliki luas persawahan sebesar 33.547 hektar (BPS Jawa Timur, 2017). Dengan luas daerah persawahan ini maka ketersediaan jerami padi pada musim panen sangat melimpah yang mempunyai potensi untuk dimanfaatkan sebagai pakan ternak.

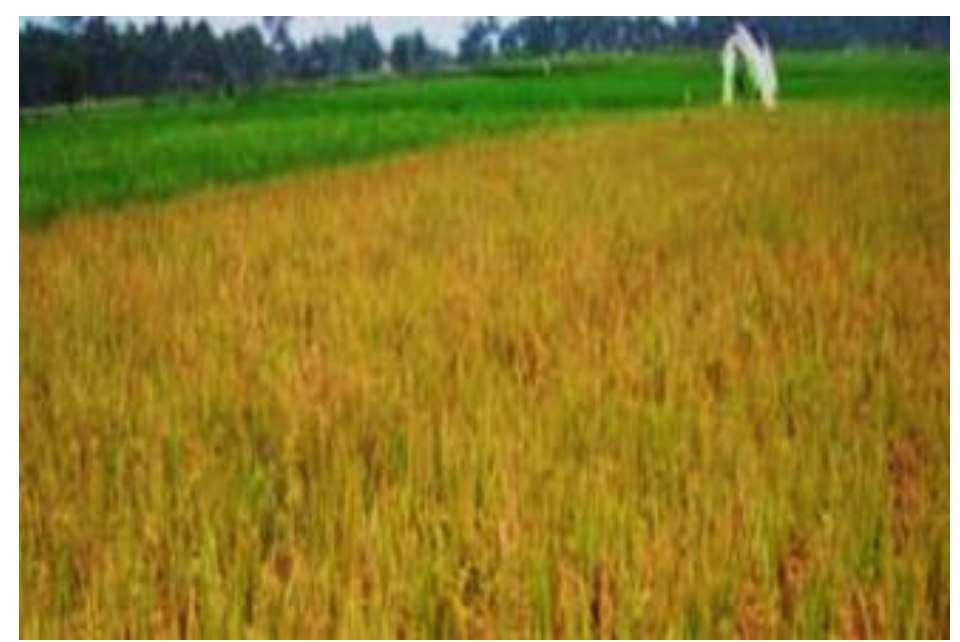

Gambar 1. Kondisi Persawahan di Desa Kalibendo

Kabupaten Lumajang merupakan salah satu kabupaten yang terletak di Jawa Timur yang memiliki potensi dalam penggembangan komoditas sapi dan kambing. Masyarakat di Desa Kalibendo mayoritas memiliki ternak sapi atau kambing dengan jumlah kepemilikan berkisar antara yaitu 2-5 ekor.

Program KKN Tematik yang dilaksanakan di Desa Kalibendo pada tahun 2019 bertemakan kewirausahaan dan wisata telah terlaksana dengan baik. Namun, hasil diskusi dengan perangkat desa dan kelompok peternak (Gambar 2). Desa Kalibendo masih mengalami kendala tentang kelangkaan pakan ternak dimusim kemarau oleh karena itu Desa Kalibendo masih membutuhkan dukungan, bimbingan, dan pelatihan mengenai manajeman pemeliharaan ternak dan manajeman pakan dengan menerapkan bioteknologi pengolahan pakan fermentasi limbah jerami padi. 


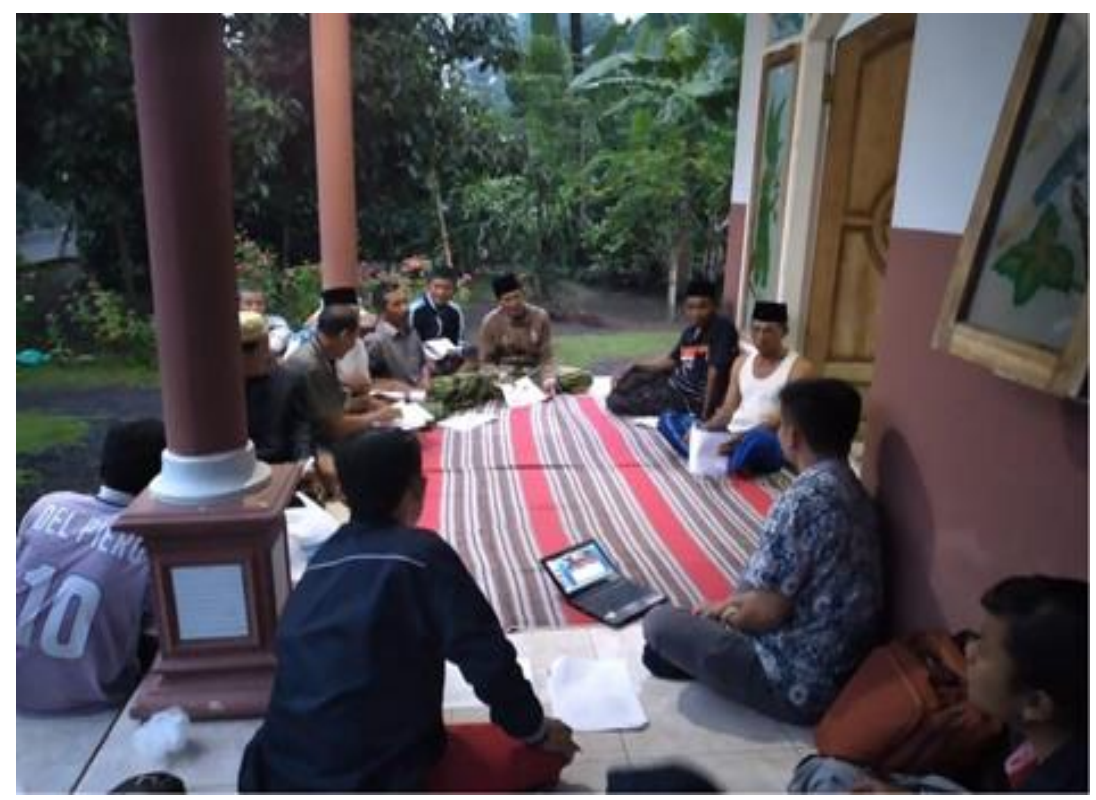

Gambar 2. Diskusi dengan perangkat desa, dan kelompok peternak di Desa Kalibendo

Sistem budidaya ternak di Desa Kalibendo juga masih dilakukan dengan sangat tradisional padahal jika dikaji dari segi potensi desa sangat mendukung diterapkannya manajemen budidaya ternak yang evisien dan menguntungkan karena memanfaatkan limbah pertanian. Strategi yang akan diterapkan untuk mengatasi masalah masyarakat peternak di Desa Kalibendo, Kecamatan Pasirian, Lumajang tersebut adalah melakukan workshop, praktek, dan pendampingan tentang manajemen budidaya ternak dan hilirisasi bioteknologi pengolahan pakan fermentasi limbah jerami padi tinggi nutrisi untuk mewujudkan kemandirian dan kesejahteraan masyarakat.

Permasalahan-permasalahan yang sering dihadapi di Desa Kalibendo, Kecamatan Pasirian, Lumajang adalah yaitu pengetahuan peternak mengenai manajeman budidaya ternak, kelanngkaan pakan di musim kemarau, komposisi nutrien jerami padi masih sanagt rendah yaitu: bahan kering $=76.60 \%$, protein kasar $=5.61 \%$, lemak kasar $=1.57 \%$, serat kasar $=25.54 \%$, total digestible nutrient $=53.07 \%$ (Utomo R. 2004). Rendahnya kandungan protein kasar dan tingginga kandungan serat kasar pada jerami padi menjadi pembatas dalam pemanfaatannya sebagai pakan ternak. 


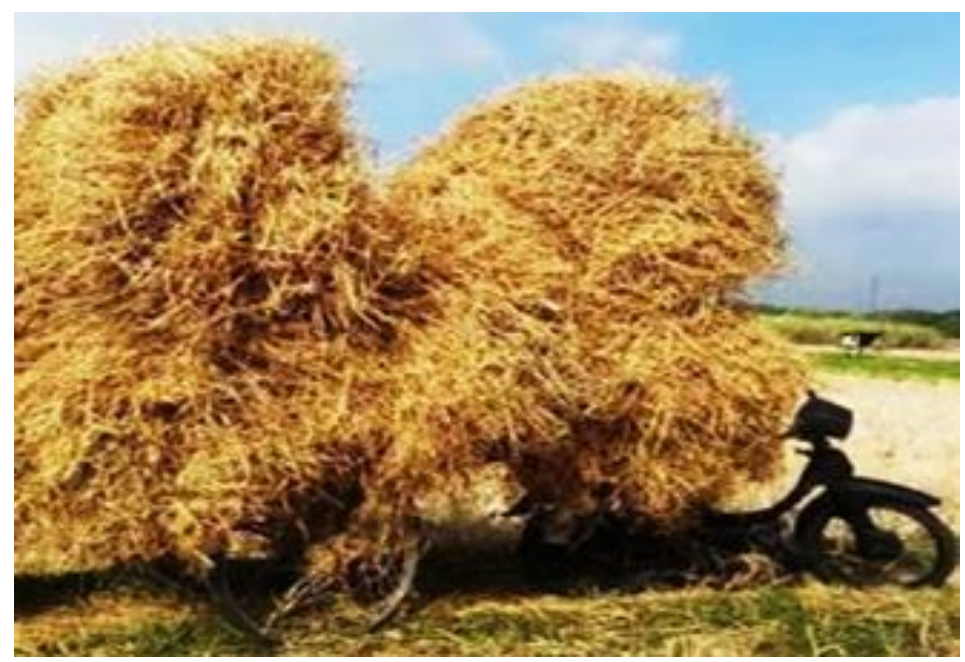

Gambar 3. Pemanfaatan jerami padi kering di Desa Kalibendo

Pengolahan bioteknologi jerami padi fermentasi tinggi nutrisi menjadi pakan ternak ruminansia merupakan salah satu solusi yang paling tepat untuk meningkatkan kandungan nutrisi, dan meningkatkan kecernaan ternak. Selain meningkatkan kandungan nutrisi, fermentasi jerami padi juga dapat memperpanjang masa simpan dari jerami padi tersebut sehingga dapat mengatasi masalah kekurangan pakan pada musim kemarau. Dengan demikian manajemen pemeliharaan pakan akan lebih mudah dan efisien yang pada akhirnya akan meningkatkan kemandirian dan kesejahteraan peternak.

Kegiatan pengabdian dilakukan dengan mengintegrasikan antara pemerintah desa, akademisi, dan masyarakat desa dalam menyelesaikan masalah yang ada di Desa Kalibendo terutama masalah manajeman budidaya ternak dan manajeman pakan ternak melalui bioteknologi fermentasi jerami padi tinggi nutrisi, guna meningkatkan kemandirian dan kesejahteraan peternak di Desa Kalibendo. Pembinaan yang dilakukan terhadap mitra meliputi yang dilakukan untuk mentransfer teknologi bidang peternakan yaitu (a) Workshop penerapan teknologi tepat guna tentang manajemen budidaya ternak. Kegiatan ini memberikan pemahaman, pengetahuan, dan keterampilan tentang manajemen budidaya ternak, manajemen perkandangan, recording, pemilihan bibit unggul dan manajemen reproduksi ternak, (b) Workshop hilirisasi bioteknologi pengolahan pakan fermentasi tinggi nutrisi dengan memanfaatkan limbah jerami padi, dan (c) Melakukan monitoring dan evaluasi serta pendampingan untuk memastikan kegiatan manajemen budidaya ternak dan manajeman pakan berjalan dengan baik. Kegiatan pengabdian ini diharapkan dapat meningkatkan keterampilan peternak Desa Kalibendo, Kecamatan Pasirian, Kabupaten Lumajang dalam manajemen budidaya ternak dan manajemen pemanfaatan pakan fermentasi dapat mendukung kemandirian dan kesejahteraan peternak. 


\section{METODE PELAKSANAAN}

\section{Tahapan Pembuatan Jerami Padi Tinggi Nutrisi}

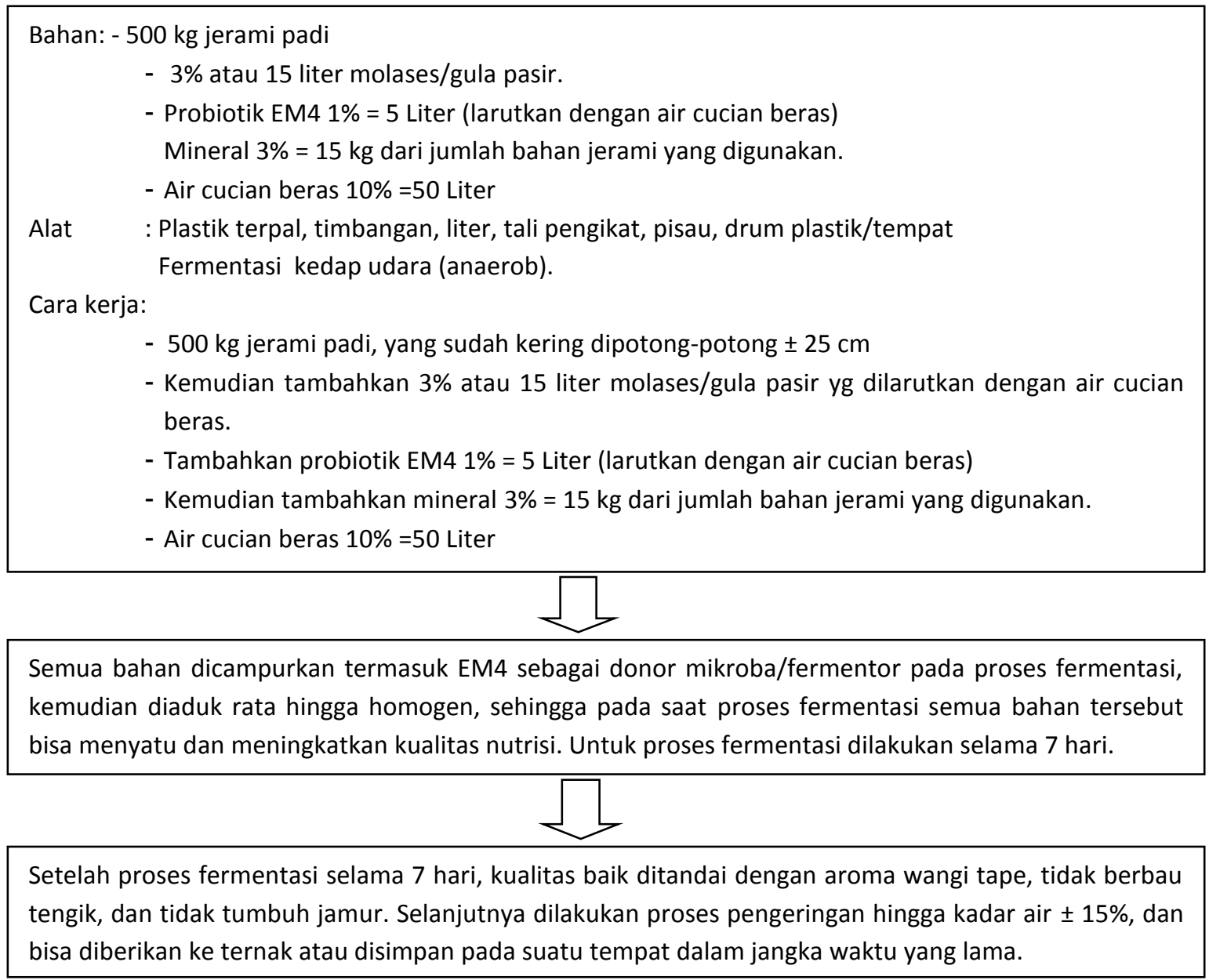

Gambar 4. Tahapan Pembuatan Jerami Padi Tinggi Nutrisi

\section{Deskripsi Pelaksanaan Kegiatan dan Pendekatan}

Kegiatan pengabdian Desa Kalibendo difokuskan pada peningkatan kemandirian peternak dan meningkatkan kesejahteraan peternak melalui hilirisasi bioteknologi pengolahan fermentasi jerami padi tinggi nutrisi. Adapun langkah-langkah pada program pengabdian desa binaan ini dilakukan secara terstruktur sebagai berikut:

1. Sosialisasi kegiatan dengan pengenalan program bioteknologi pengolahan pakan fermentasi jerami padi tinggi nutrisi.

2. Workshop dan peraktek bioteknologi pengolahan pakan ternak fermentasi limbah jerami.

3. Monitoring, evaluasi, aplikasi pakan fermentasi agar berjalan dengan baik.

\section{Agenda Kegiatan}


Agenda kegiatan pada pengabdian desa binaan di Desa Kalibendo, Kecamatan Pasirian, Kabupaten Lumajang dilakukan sebagai berikut:

1. Pra Kegiatan dilakukan pada bulan September 2020. Kegiatan ini bertujuan untuk memantapkan program dan rencana strategi pelaksanaan program pengabdian desa binaan di Desa Kalibendo. Hasil diskusi dengan kepala desa, perangkat desa, dan kelompok tani-ternak didapatkan masalah yang akan di cari solusinya yaitu: a) Memperbaiki manajemen ternak yang masih sangat tradisional, b) kelangkaan pakan di musim kemarau, c) kualitas nutrisi jerami padi masih sangat rendah.

2. Workshop tentang manajemen dan aplikasi bioteknologi pengolahan limbah jerami sebagai pakan ternak tinggi nutrisi dilaksanakan selama dua minggu, dimulai $4-18$ Oktober 2020. Gambaran alur bioteknologi fermentasi jerami padi dapat dilihat pada gambar 4.

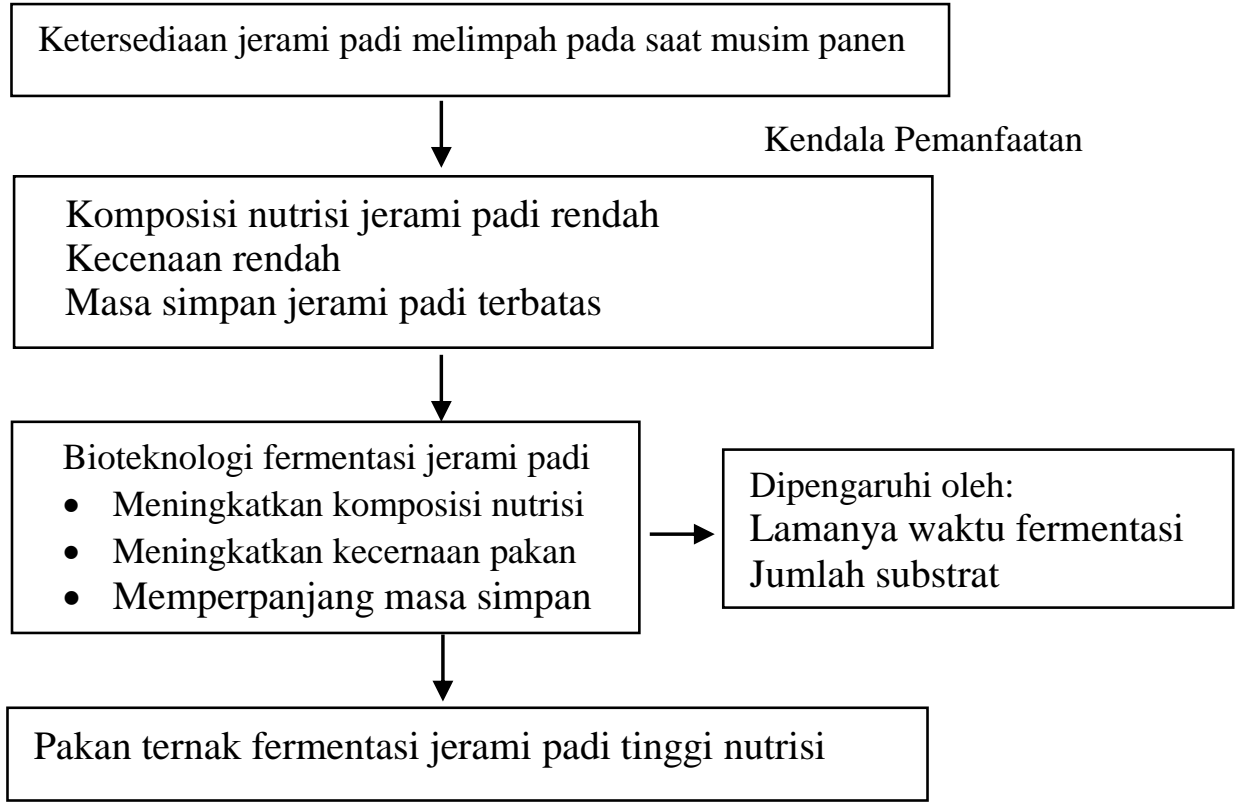

Gambar 5. Alur bioteknologi fermentasi jerami padi

\section{Kelompok Sasaran}

Kelompok sasaran kegiatan pengabdian desa binaan adalah petani-peternak dan karangtaruna di Desa Kalibendo, Kecamatan Pasirian, Kabupaten Lumajang yang memiliki kemauan dan antusias yang tinggi untuk menerima program pengabdian desa binaan untuk menambah pengetahuan dan keterampilan dibidang manajeman bioteknologi pengolahan pakan ternak. 


\section{Pelatihan}

Pelatihan disampaikan melalui workshop dan praktek dengan cara presentasi, diskusi, dan pendampingan terhadap petani/peternak di Desa Kalibendo, dengan harapan dapat meningkatkan pengetahuan dan keterampilan dalam manajeman budidaya ternak dan pengolahan pakan ternak fermentasi tinggi nutrisi menggunakan limbah jerami padi.

\section{Uraian Teknologi}

Hilirisasi bioteknologi yang digunakan dapat mengatasi kelangkaan pakan dimusim kemarau meningkatkan kualitas nutrien pakan, memperpanjang masa simpan pakan dengan memanfaatkan limbah jerami padi. Uraian tujuan dan nilai tambah dari hilirisasi bioteknologi fermentasi limbah jerami disajikan pada tabel 1.

Tabel 1. Nilai tambah hilirisasi bioteknologi pengolahan pakan fermentasi

\begin{tabular}{|c|c|c|}
\hline \multicolumn{2}{|c|}{ No Tujuan Segi } & Nilai Tambah \\
\hline & & Jenis teknologi tepat guna \\
\hline \multirow[t]{3}{*}{1} & Teknologi & Mudah dipahami \\
\hline & & Murah dan sederhana \\
\hline & & Mudah dioperasikan tanpa training \\
\hline \multirow[t]{2}{*}{2} & Operasional & Tidak rumit pemeliharaannya \\
\hline & & Hemat dan murah \\
\hline 3 & $\begin{array}{l}\text { Pengaruh workshop dan praktek } \\
\text { manajemanBudidaya ternak dan } \\
\text { bioteknologi pengolahan pakan } \\
\text { fermentasi }\end{array}$ & $\begin{array}{l}\text { Peternak memahami dan mengaplikasikan } \\
\text { manajeman budidaya dan manajeman pakan } \\
\text { dengan baik, benar, dan efisien sehingga lebih } \\
\text { mandiri dan sejahtera }\end{array}$ \\
\hline 4 & Modifikasi & $\begin{array}{l}\text { Menjadikan desa sebagai sentra peternakan dan } \\
\text { penggunaan bahan pakan fermentasi baku lokal dan } \\
\text { limbah pertanian menjadi pakan sehingga memiliki } \\
\text { nilai guna dan menjadi pakan alternatif yang } \\
\text { memiliki nilai jual. }\end{array}$ \\
\hline 5 & Dampak sosial & $\begin{array}{l}\text { Meningkatkan kemandirian dan kesejahteraan } \\
\text { peternak. }\end{array}$ \\
\hline
\end{tabular}

\section{Rancangan Evaluasi}

Evaluasi keberhasilan program hilirisasi bioteknologi pengolahan pakan fermentasi limbah jerami padi di Desa Kalibendo dilakukan setelah proses sosialisasi, workshop dan praktek (sesuai jadwal terlampir). Rencana evaluasi program pengabdian desa binaan dapat dilihat pada tabel 2. 
Tabel 2. Rancangan evaluasi program pengabdian desa binaan di desa Kalibendo

\begin{tabular}{llll}
\hline No & Kriteria & Indikator & Tolak Ukur \\
\hline 1 & $\begin{array}{l}\text { Kapasitas sumber } \\
\text { daya manusia }\end{array}$ & $\begin{array}{l}\text { Perubahan } \\
\text { perilaku } \\
\text { sosial }\end{array}$ & $\begin{array}{l}\text { Mampu membudidayakan ternak, } \\
\text { menguasai } \\
\text { bioteknologi } \\
\text { pengolahan pakan fermentasi, dan } \\
\text { mengaplikasikannya dengan baik }\end{array}$ \\
& $\begin{array}{l}\text { Hasil } \\
\text { produksi }\end{array}$ & $\begin{array}{l}\text { Produktivitas ternak } \\
\text { Evisiensi pakan ternak }\end{array}$ & $\begin{array}{l}\text { Keberhasilan meningkatkan } \\
\text { Produktivitas ternak } \\
\text { Kebrhasilan mengolah pakan } \\
\text { fermentasi limbah jerami padi }\end{array}$ \\
& Sosial ekonomi & Kondisi masyarakat & $\begin{array}{l}\text { Meningkatkan kemandirian dan } \\
\text { kesejahteraan petani-peternak }\end{array}$ \\
& &
\end{tabular}

\section{HASIL, PEMBAHASAN, DAN DAMPAK}

Program Pengabdian Desa Binaan (PPDB) dengan topik "Bioteknologi Fermentasi Jerami Padi Tinggi Nutrisi, Guna Meningkatkan Kemandirian dan Kesejahteraan Peternak di Desa Kalibendo. Adapun langkah-langkah yang dilakukan dalam program pengabdian desa binaan antara lain sebagai berikut:

1. Sosialisasi pentingnya pemanfaatan limbah pertanian berupa jerami padi untuk diolah menggunakan bioteknologi fermentasi sebagai pakan ternak tinggi nutrisi di Desa Kalibendo, Kecamatan Pasiria, Kabupaten Lumajang..

2. Pemanfaatan limbah jerami padi tinggi nutrisi dapat memenuhi kebutuhan hidup pokok dan produksi ternak, juga dapat digunakan secara berkelanjutan ataupun pada saat musim kemarau dengan terbatasnya hijauan pakan ternak.

3. Memberikan pelatihan pada petani/peternak mengenai cara melakukan Bioteknologi Fermentasi Jerami Padi Tinggi Nutrisi, Guna Meningkatkan Kemandirian dan Kesejahteraan Peternak di Desa Kalibendo, Kecamatan Pasirian, Kabupaten Lumajang.

Banyaknya jumlah pakan dikonsumsi oleh seekor ternak merupakan salah satu faktor penting secara langsung mempengaruhi produktivitas ternak, baik untuk kebutuhan hidup pokok, produksi maupun pada fase pertumbuhan (Prasetyo dan Awaludin. 2016). Konsumsi pakan dipengaruhi terutama oleh faktor kualitas pakan, dan kebutuhan energi ternak. Kualitas pakan dikatakan baik ketika semakin tinggi konsumsi, dan tingkat kecernaandari seekor ternak. Dampak dari penentuan konsumsi pakan berkualitas baik bisa ditentukan dari status fisiologi seekor ternak (palatabilitas dan kecernaan dari pakan yang diberikan). 
Bahan Kering (BK) merupakan tolak ukur dalam menilai palatabilitas pakan, serta diperlukan untuk menentukan mutu/kualitas pakan ternak.

\section{SIMPULAN}

Dari hasil kegiatan Program Pengabdian Desa Binaan (PPDB) dengan topik Bioteknologi Fermentasi Jerami Padi Tinggi Nutrisi, Guna Meningkatkan Kemandirian dan Kesejahteraan Peternak di Desa Kalibendo, Kecamatan Pasiria, Kabupaten Lumajang sangat dibutuhkan peranan perangkat desa guna memotivasi petani/peternak dalam meningkatkan sumberdaya manusia peternak untuk lebih maju dan berkembang, terutama dalam memanfaatkan potensi limbah hasil pertanian yang sangat berlimpah untuk dijadikan pakan ternak. Perlu dilakukan proses dan evaluasi dalam program pengabdian desa binan.

\section{UCAPAN TERIMAKASIH}

Tim Program Pengabdian Desa Binaan (PPDB) mengucapkan terima kasih kepada LP2M (Lembaga Penelitian dan Pengabdian kepada Masyarakat) Universitas Jember; b) KeRis (Kelompok Riset) Animal Breeding and Production); c) PS Peternakan Fakultas Pertanian Universitas Jember; e) Perangkat Desa Kalibendo, Kecamatan Pasiria, Kabupaten LumajangProvinsi Jawa Timur.

\section{DAFTAR PUSTAKA}

Arofi, F., Rukmana, D., Ibrahim, B. 2015. The analysis of integration sustainability of coffe plantation and goat husbandry (a case study in Ampelgading subdistrict, Malang Regency, East Java, Indonesia). Journal of Economics and Sustainable Development 6(10): 1-12.

BPS Jawa Timur. 2017. Indikator Pertanian Provinsi Jawa Timur.

Moraine, M., Duru, M., Therond, O. 2017. A social ecological framework for analyzing and designing integrated crop- livestock system from farm to territory levels. Rewenable Agriculture and Food Systems 32(1): 43-56. https://doi.org/10.1017/S1742170515000526

Prasetyo AF dan Awaludin A. 2016. Peran kelembagaan peternak dalam adopsi teknologi. Jurnal Ilmiah Inovasi 1 (2): 133-137. https://doi.org/10.25047/jii.v16i2.298 
Utomo, R., 2004. Review Hasil-Hasil Penelitian Pakan Sapi Potong. Lokakarya Nasional Sapi Potong 2004. Fakultas Peternakan. Universitas Gadjah Mada. Yogyakarta. 14 (3): $13-14$

Wulandari. 2014. Phylogenetic analysis and predicted functional effect of protein mutations of E6 and E7 HPV16 strains isolated in Indonesia. Medical Journal of Indonesia. https://doi.org/10.13181/mji.v24i4.1197 